\title{
Microstructure, Mechanical Properties, and In Vitro Corrosion Behavior of Biodegradable Zn-1Fe-xMg Alloy
}

\author{
Penghao Xue ${ }^{1,2,3,4}$, Minglong Ma ${ }^{1,3,4}$, Yongjun $\mathrm{Li}^{1,3,4}$, Xinggang $\mathrm{Li}^{1,3,4}$, Jiawei Yuan ${ }^{1,3,4}$, \\ Guoliang Shi ${ }^{1,3,4}$, Kaikun Wang ${ }^{2}$ and Kui Zhang 1,3,4,* \\ 1 State Key Laboratory of Nonferrous Metals and Processes, GRIMAT Engineering Institute Co., Ltd., \\ Beijing 100088, China; b20170187@xs.ustb.edu.cn (P.X.); maminglong@grinm.com (M.M.); \\ lyj@grinm.com (Y.L.); lxg1218@grinm.com (X.L.); yuanjiawei@grinm.com (J.Y.); shigl@grinm.com (G.S.) \\ 2 School of Materials Science and Engineering, University of Science \& Technology Beijing, \\ Beijing 100083, China; kkwang@mater.ustb.edu.cn \\ 3 GRIMAT Engineering Institute Co., Ltd., Beijing 101407, China \\ 4 General Research Institute for Nonferrous Metals, Beijing 100088, China \\ * Correspondence: zhkui@grinm.com
}

Received: 10 October 2020; Accepted: 23 October 2020; Published: 29 October 2020

\begin{abstract}
Zinc (Zn), one of the promising candidates for biodegradable implant materials, has excellent biocompatibility and biodegradability. In this study, as-cast Zn1FexMg ( $x \leq 1.5 \mathrm{wt} \%)$ alloys were prepared to systematically explore the effects of magnesium $(\mathrm{Mg})$ alloying on their microstructures, mechanical properties, and biodegradability. The microstructure of Zn1FexMg alloy consisted of $\mathrm{Zn}$ matrix, $\mathrm{Zn}+\mathrm{Mg}_{2} \mathrm{Zn}_{11}$ eutectic structure, and $\mathrm{FeZn}_{13}$ phase. The addition of $\mathrm{Mg}$ not only promoted grain refinement of the alloy, but also improved its mechanical properties. The results of immersion tests showed that the addition of $\mathrm{Mg}$ accelerated microcell corrosion between different phases, and the modeling of the corrosion mechanism of alloys in simulated body fluid (SBF) solution was discussed to describe the interaction between different phases in the corrosion process. $\mathrm{Zn} 1 \mathrm{Fe} 1 \mathrm{Mg}$ possessed superior comprehensive mechanical properties and appropriate corrosion rate, and the values for hardness, tensile strength, yield strength, elongation, and corrosion rate were $105 \mathrm{HB}, 157 \mathrm{MPa}$, $146 \mathrm{MPa}, 2.3 \%$, and $0.027 \mathrm{~mm} / \mathrm{a}$, respectively, thus revealing that $\mathrm{Zn} 1 \mathrm{Fe} 1 \mathrm{Mg}$ is a preferred candidate for biodegradable implant material.
\end{abstract}

Keywords: Zn-Fe-Mg alloy; mechanical properties; electrochemical; corrosion model

\section{Introduction}

In addition to having excellent biocompatibility, good biodegradable metal materials should provide adequate support during the cytothesis and the remodeling of tissue, for example during bone and vascular remodeling. Once bone and vascular remodeling have been accomplished, the degradation should occur as quickly as possible to avoid stress shielding or secondary blockage [1,2]. Early studies mainly focused on pure Iron $(\mathrm{Fe})$ and Magnesium $(\mathrm{Mg})$ and their alloys due to their excellent biocompatibility. However, Fe-based alloys possess a low degradation rate, and their harmful corrosion products impair the integrity of the arterial wall [3-7]. Mg-based alloys have unsatisfactory mechanical properties and the accelerated corrosion rates in physiological environments predispose them towards premature loss of mechanical integrity as well as gas embolism due to the harmful corrosion-linked formation of hydrogen gas [8-11]. Thus, researchers are eager to identify other types of alloys, which can replace the above-mentioned alloys, among them Zinc (Zn) and Zn-based alloys. 
Zn element plays an important role in the biological functions of the human body because it is involved in all aspects of cell metabolism. It also supports immune function, protein and DNA synthesis, and wound healing [12-15]. Zn exhibits high chemical activity, with an electrode potential value between that of $\mathrm{Mg}$ and $\mathrm{Fe}$. Thus, $\mathrm{Zn}$ has received attention in recent years due to its good performance and biocompatibility. In animal experiments, pure $\mathrm{Zn}$ implants placed in porcine arteries have shown good biocompatibility [13]. However, a previous study showed that pure $\mathrm{Zn}$ has very low mechanical strength. Under casting and forging conditions, the ultimate tensile strength (UTS) of pure $\mathrm{Zn}$ is only $20 \mathrm{MPa}$ and $120 \mathrm{MPa}[16,17]$. Current efforts to counteract the inherent disadvantageous properties of $\mathrm{Zn}$ alloys are largely focused on alloying and improved processing conditions. The $\mathrm{Zn}-\mathrm{Fe}$ base alloys in particular have attracted great attention as iron is one of the most abundant nutritional elements in the human body [18-20]. As observed in the Zn-Fe binary phase diagram [21], a peritectic reaction occurs during solidification, which forms primary Fe-Zn binary phases. The needle-shaped Fe-Zn phase and the Zn matrix form a structure similar to "reinforced concrete", which significantly improves the mechanical properties. The Fe- $\mathrm{Zn}$ phase and the $\mathrm{Zn}$ matrix will also cause microcell corrosion, which accelerates the degradation rate of implants made from $\mathrm{Zn}$ alloys [18]. Alon Kafri et al. implanted a cylindrical disk made of as-cast $\mathrm{Zn}-2 \mathrm{wt} \%$ Fe alloy into the back midline of male Wistar rats for 24 weeks. Results of well-being, hematological testing, and histological analysis in rats indicated that the in-vivo behavior of $\mathrm{Zn}-2 \% \mathrm{Fe}$ implants was satisfactory [19]. However, the elongation of the as-cast $\mathrm{Zn}-1.3 \mathrm{Fe}$ alloy is even less than $2 \%$ [17]. The coarse Fe- $\mathrm{Zn}$ phases weaken the plasticity and make alloys with high brittleness, which limits the potential application prospect.

In order to reduce the brittleness of the alloy, the amount of Fe added must be restricted within $1 \mathrm{wt} \%$. Thus, in order to further optimize the comprehensive properties of $\mathrm{Zn}$-Fe alloy, Mg element was considered to be a microalloying element based on the following reasons. Firstly, $\mathrm{Mg}$ is a commonly added element in $\mathrm{Zn}$-based biodegradable alloy, and $\mathrm{Zn}-\mathrm{Mg}$ binary alloys have already been extensively explored [22-25]. Secondly, the addition of a small amount of $\mathrm{Mg}$ to pure $\mathrm{Zn}$ helps to form eutectic structures $\left(\mathrm{Mg}_{2} \mathrm{Zn}_{11}+\mathrm{Zn}\right)$ at the grain boundaries, hindering the grain growth, thus enhancing the mechanical properties. Thirdly, the $\mathrm{Mg}_{2} \mathrm{Zn}_{11}$ phase may act as an anodic phase to $\mathrm{Zn}$ matrix and $\mathrm{FeZn} \mathrm{n}_{13}$ phase, causing accelerated corrosion via microcell corrosion, because the high potential difference among $\mathrm{Mg}_{2} \mathrm{Zn}_{11}, \mathrm{FeZn}_{13}$, and $\mathrm{Zn}$ may cause microcell corrosion. Some scholars improve the properties of the alloy by adding elements such as $\mathrm{Ca}, \mathrm{Sr}, \mathrm{Al}$ to $\mathrm{Zn}-\mathrm{Mg}$ [26-28]. Some of these elements seem to play the same role as Fe. For example, $\mathrm{CaZn}_{13}$ strengthens the mechanical properties of $\mathrm{Zn}-\mathrm{Mg}$-Ca and promote its degradation. However, $\mathrm{Ca}$ and $\mathrm{Sr}$ are very expensive, and they are so active that the preparations are more complicated. $\mathrm{Al}$ is not the first element in the alloying of degradable alloys because of its negative effects on the human body. Lastly, due to the "reinforced concrete" structure of alloy, the existence of the needle-like Fe-Zn phase ensures that preferential corrosion cracking at the grain boundaries does not cause premature failure of the implants. It may ensure the ability of long-term support to blood vessels or bones during their lifespan. In this study, in order to comprehend mechanical properties and accelerate the degradation rate of $\mathrm{Zn}$-Fe alloy as a biodegradable candidate material, $\mathrm{Zn}-1 \mathrm{Fe}-\mathrm{xMg}(\mathrm{x}=0.5-1.5 \mathrm{wt} \%)$ alloys were designed, with an aim to explore the influence of $\mathrm{Mg}$ on the microstructure, mechanical properties, and corrosion characteristics of the biodegradable $\mathrm{Zn}-1 \mathrm{Fe}-\mathrm{Mg}$. A corrosion model of the alloy was established to determine the interaction between different phases of in vitro corrosion behavior of alloys to provide basic guidance for $\mathrm{Mg}$ alloying in biodegradable Zn-Fe alloys.

\section{Experimental}

\subsection{Material Preparation}

Zn1FexMg alloys with different $\mathrm{Mg}$ contents $(0.5,1.0$, and $1.5 \mathrm{wt} \%)$ were prepared by gravity casting under a protective atmosphere of Argon (Ar) and tetrafluoroethane R-134a to inhibit the oxidation of $\mathrm{Mg}$. Boron carbide was sprayed on the surface of the cylindrical cast iron crucibles with a 
size of $\varphi 100 \times 200 \mathrm{~mm}$ to prevent the surface reaction with Zn during the smelting process. Zn ingots (purity $>99.99 \%$ ) were melted in the crucible at $500{ }^{\circ} \mathrm{C}$. Heating was continued until $650{ }^{\circ} \mathrm{C}$ was reached, and the $\mathrm{Mg}$ ingots (purity $>99.90 \%$ ) were pressed into the bottom of the solution with a bell jar. After the Mg ingots melted, the iron powder (purity $>99.90 \%$ ) was pressed into the melt with a bell jar. The melt was homogenized by intense mechanical stirring, and then it was poured into a permanent mold. The obtained $\mathrm{Zn}-1 \mathrm{Fe}-\mathrm{xMg}$ alloys were cut into samples of different sizes for follow-up testing. The chemical compositions of samples tested by Inductively Coupled Plasma Optical Emission Spectrometry (ICP-OES, Agilent 725, Agilent, Santa Clara, CA, USA) are shown in Table 1. As the reference burning loss rates of the alloying elements were not consistent with the actual burning loss rate of the alloying elements, there was a difference between the calculated and actual components of the alloy.

Table 1. The actual components of alloys measured by Inductively Coupled Plasma Optical Emission Spectrometry (ICP-OES).

\begin{tabular}{cccccccc}
\hline & & & \multicolumn{4}{c}{ Measured Composition (wt \%) } \\
\cline { 4 - 7 } Number & \multirow{2}{*}{ Symbol } & Nominal Composition (wt \%) & Zn & Fe & Mg & Cu & Sn \\
\hline$\# 1$ & & $Z n$ & 99.99 & $<0.001$ & $<0.001$ & $<0.002$ & $<0.001$ \\
$\# 2$ & $Z n 1 F e 0.5 M g$ & $Z n-1 w t \% F e-0.5 w t \% M g$ & 98.43 & 0.93 & 0.6 & $<0.002$ & $<0.001$ \\
$\# 3$ & $Z n 1 F e 1 M g$ & $Z n-1 w t \% F e-1 w t \% M g$ & 97.81 & 0.9 & 1.25 & $<0.002$ & $<0.001$ \\
$\# 4$ & $Z n 1 F e 1.5 M g$ & $Z n-1 w t \% F e-1.5 w t \% M g$ & 97.12 & 0.98 & 1.85 & $<0.002$ & $<0.001$ \\
\hline
\end{tabular}

\subsection{Material Characterization}

All samples used for microscopic observation were mechanically polished to $1 \mu \mathrm{m}$ and etched with dilute nitric acid solution. The microstructures of Zn1FexMg alloys were observed using an optical microscope (Axiovert-200MAT, Zeiss, Jena, Germany) and scanning electron microscopy (SEM, JSM-7610F, Jeol, Tokyo, Japan) equipped with energy dispersive spectroscopy (EDS, AMETEK EDAX, Berwyn, PA, USA). Moreover, the X-ray diffractometer (XRD, Xpert Pro, PANalytical, Amsterdam, Netherlands) with $\mathrm{Cu}-\mathrm{K} \alpha$ radiation was used to identify the phases in alloys. The scan angle range was $10-90^{\circ}$, the diffraction parameter was $40 \mathrm{kV} / 30 \mathrm{~mA}$, and the scan rate was $2^{\circ} / \mathrm{min}$.

The mechanical properties of the samples were tested according to the ASTM-E8/E8m-11 standard [10] with a crosshead speed of $1 \mathrm{~mm} / \mathrm{min}$ on the universal material test machine (SANS, CMT5504, USA). The Brinell hardness value of polished samples was measured using an Brinell hardness tester (XHB-3000, Wuhan, China). The applied load was $3000 \mathrm{Kgf}$ and the residence time was $15 \mathrm{~s}$.

\subsection{In Vitro Corrosion Assay}

The electrochemical impedance spectroscopy (EIS) test and the potentiodynamic polarization test were conducted in the SBF solution (PH1820-phygene) at $37^{\circ} \mathrm{C}$ using an electrochemical workstation $(\mathrm{CS} 2350 \mathrm{H})$. The ionic compositions $(\mathrm{mM})$ of SBF were $142.0 \mathrm{Na}^{+}, 5.0 \mathrm{~K}^{+}, 1.5 \mathrm{Mg}^{2+}, 2.5 \mathrm{Ca}^{2+}, 103.0 \mathrm{Cl}^{-}$, $10.0 \mathrm{HCO}^{-}{ }_{3}, 1.0 \mathrm{HPO}^{2-}{ }_{4}, 0.5 \mathrm{SO}^{2-}{ }_{4}$. The $\mathrm{Zn} 1 \mathrm{FexMg}$ alloy was the working electrode, the platinum sheet was the counter electrode, and $\mathrm{Ag} / \mathrm{AgCl} /$ in saturated $\mathrm{KCl}$ electrode was the reference electrode. The sample was wrapped in epoxy resin, and only a surface area of $1 \mathrm{~cm}^{2}$ was exposed to the SBF solution during the electrochemical test. In order to obtain a relatively stable potential value, the open-circuit potential (OCP) test was performed before the EIS and the polarization experiments for $1800 \mathrm{~s}$. The EIS measurements were carried out between $0.01 \mathrm{~Hz}$ and $100 \mathrm{kHz}$ at $10 \mathrm{mV}$ amplitude. The potentiodynamic polarization tests were conducted using a scan rate of $1 \mathrm{mV} / \mathrm{s}$ and a scan range from -1600 to $-400 \mathrm{mV}$. The corrosion current density was calculated by extrapolating the polarization curve, and the corrosion rate was calculated according to the ASTM-G102-89 standard [29]. The surface morphology of the specimens after electrochemical tests was further observed by SEM.

The immersion tests were performed in SBF solution according to the ASTM G31-12a standard [30]. The rectangular parallelepiped samples with an exposed area of $3 \mathrm{~cm}^{2}$ were immersed in a $60 \mathrm{~mL}$ SBF 
solution at $37^{\circ} \mathrm{C}$ for $720 \mathrm{~h}$ and the SBF solution was renewed every $48 \mathrm{~h}$. Then, the surface morphology was observed using SEM and corrosion products were identified by EDS. The corrosion products of tested samples were removed by means of immersion in an aqueous solution containing $\mathrm{CrO}_{3}$. Then the corrosion rate of the alloy was calculated.

\section{Results and Discussion}

\subsection{Surface Morphologies and Phase Structure}

Optical micrographs of the microstructures of cast samples are shown in Figure 1. The grains in pure $\mathrm{Zn}$ were large and the grain size exceeded $300 \mu \mathrm{m}$, as shown in Figure 1a. Figure 1b-d show the microstructures of $\mathrm{Zn} 1 \mathrm{FexMg}$ alloys, which consisted of primary $\mathrm{Zn}$ dendrites, $\mathrm{FeZn}_{13}$ acicular structure, and eutectics along the grain boundaries. EDS analyses (see Figure 1g-i) of alloys showed that the eutectics (dark lamellar areas) consisted of $\mathrm{Zn}$ and $\mathrm{Zn}-\mathrm{Mg}$ intermetallic compound, and the needle-like structures (white areas) were Fe- $\mathrm{Zn}$ intermetallic compounds, as confirmed by XRD in Figure 2. The $\mathrm{FeZn}_{13}$ phase nucleated and grew before the other phases, according to the $\mathrm{Zn}-\mathrm{Mg}$ and $\mathrm{Zn}-\mathrm{Fe}$ phase diagrams [25]. Thus, $\mathrm{FeZn}_{13}$ may be the nucleated particle of other phases. Optical micrographs did not reflect the true morphology and distribution of the $\mathrm{FeZn}_{13}$ phase. These parameters could be determined by the surface morphology of the corrosion pits in the $\mathrm{Zn} 1 \mathrm{Fe} 0.5 \mathrm{Mg}$ alloy after immersion in SBF solution for 45 days, as shown in Figure 1f. The eutectic structures at the location of the corrosion pits were corroded completely because they have a more negative potential as the anode, leaving the deeper pits shown in Figure 1f. Most of the $\mathrm{Zn}$ matrix is corroded, and the remaining part is shown in Figure $1 \mathrm{f}$ as small bumps. The $\mathrm{FeZn}_{13}$ phase had a more positive potential as the cathode to be protected, thus exposing the uncorroded $\mathrm{FeZn}_{13}$ phase, which showed a prismatic shape, with a length ranging between $100 \mu \mathrm{m}$ and $500 \mu \mathrm{m}$, and it interlaced with the matrix. Corrosion properties of alloys are discussed in Section 3 of this chapter. As the $\mathrm{Mg}$ content increased, the volume fraction of the eutectic structure of the alloy increased, as shown in Figure $1 \mathrm{~b}-\mathrm{d}$. The volume fraction of the eutectic structure of $\mathrm{Zn} 1 \mathrm{Fe} 1.5 \mathrm{Mg}$ was higher than that of the other samples, and it was clearly seen that the eutectic structure contained a submicron-sized mixture of $\mathrm{Zn}$ and $\mathrm{Mg}_{2} \mathrm{Zn}_{11}$ (see Figure 1d).

The $\mathrm{Zn}$ grain size of $\mathrm{Zn} 1 \mathrm{FexMg}$ alloys was substantially smaller than that of pure $\mathrm{Zn}$. The average size of $\mathrm{Zn}$ grains increased initially and then decreased with an increase in $\mathrm{Mg}$ content; the $\mathrm{Zn}$ grain size of $\mathrm{Zn} 1 \mathrm{Fe} 1 \mathrm{Mg}$ alloys reached a minimum value of $22.08 \mu \mathrm{m}$, as shown in Table 2 . The reason behind $\mathrm{Zn}$ grain growth in $\mathrm{Zn} 1 \mathrm{Fe} 1.5 \mathrm{Mg}$ was that the high-volume fraction of the eutectic structure caused segregation of $\mathrm{Zn}$ during solidification (see Table 2). The section size of $\mathrm{FeZn}_{13}$ increased significantly, from 28.23 to $38 \mu \mathrm{m}$. According to the $\mathrm{Zn}$-Fe phase diagram [25], there was a wide temperature range for the formation of $\mathrm{FeZn}_{13}$ by the peritectic reaction and it extended from $530{ }^{\circ} \mathrm{C}$ to room temperature. The size of $\mathrm{FeZn}_{13}$ was affected by the solidification cooling rate and hindrance of the $\mathrm{Zn}$ matrix. When the cooling rate was constant, the volume fraction of the eutectic structure with a low melting point increased and it reduced the hindering effect of the matrix on $\mathrm{FeZn} \mathrm{n}_{13}$, which can grow over a wider temperature range. The above reason can explain the growth of $\mathrm{Fe} \mathrm{Zn}_{13}$ particles.

Table 2. Grain sizes of alloys and FeZn13 phase size of alloy samples.

\begin{tabular}{ccccc}
\hline Samples & Pure Zn & Zn1Fe0.5Mg & Zn1Fe1Mg & Zn1Fe1.5Mg \\
\hline Size of Zn grain & $312.54 \mu \mathrm{m}$ & $38.80 \mu \mathrm{m}$ & $22.08 \mu \mathrm{m}$ & $38.04 \mu \mathrm{m}$ \\
Section size of FeZn $\mathrm{n}_{13}$ & & $36.13 \mu \mathrm{m}$ & $38.10 \mu \mathrm{m}$ & $62.65 \mu \mathrm{m}$ \\
\hline
\end{tabular}

XRD tests were performed to investigate the effect of different $\mathrm{Mg}$ contents on the phases of Zn1FexMg alloys, as shown in Figure 2. The tested samples had obvious characteristic peaks of Zn, $\mathrm{Mg}_{2} \mathrm{Zn}_{11}, \mathrm{FeZn}_{13}$, and $\mathrm{MgZn} \mathrm{n}_{2}$. With an increase in $\mathrm{Mg}$, the peaks of $\mathrm{Mg}_{2} \mathrm{Zn}_{11}$ increased significantly. When the $\mathrm{Mg}$ content was increased to $1.5 \mathrm{wt} \%$, significantly more peaks of the eutectic structure were detected. 

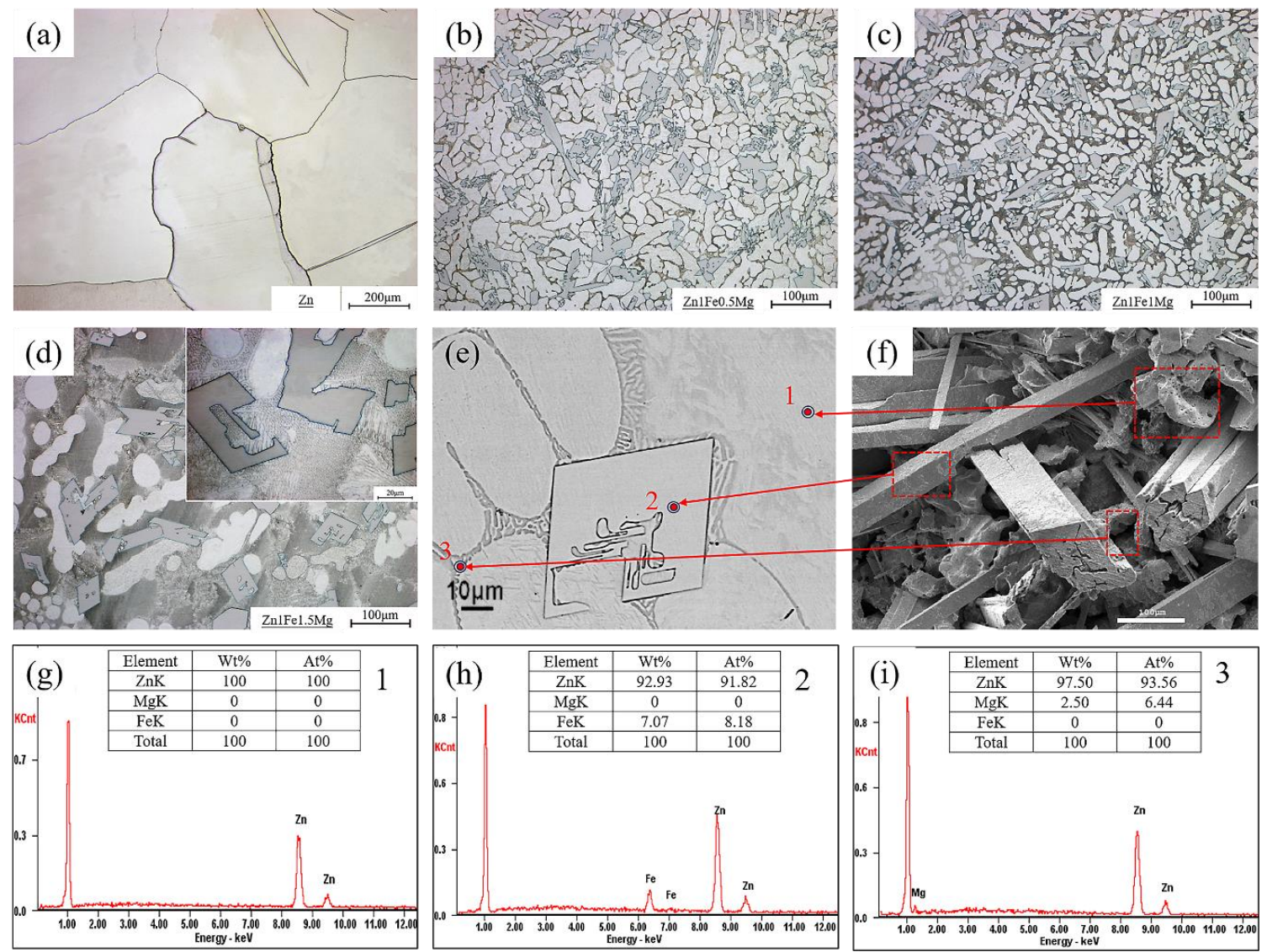

Figure 1. Micrographs of alloys with different $\mathrm{Mg}$ contents and results of energy dispersive spectroscopy (EDS) analysis: (a)cast Zn, (b) Zn-1.0Fe-0.5Mg, (c) Zn-1.0Fe-1.0Mg, and (d) Zn-1.0Fe-1.5Mg, (e) morphology of the $\mathrm{Zn} 1 \mathrm{Fe} 0.5 \mathrm{Mg}$ alloy in the scanning electron microscopy (SEM) image; (f) the surface morphology of Zn1Fe0.5Mg after removing the corrosion products; (g-i) the EDS composition analysis of the points corresponding to the positions 1,2 , and 3 of (e), respectively.

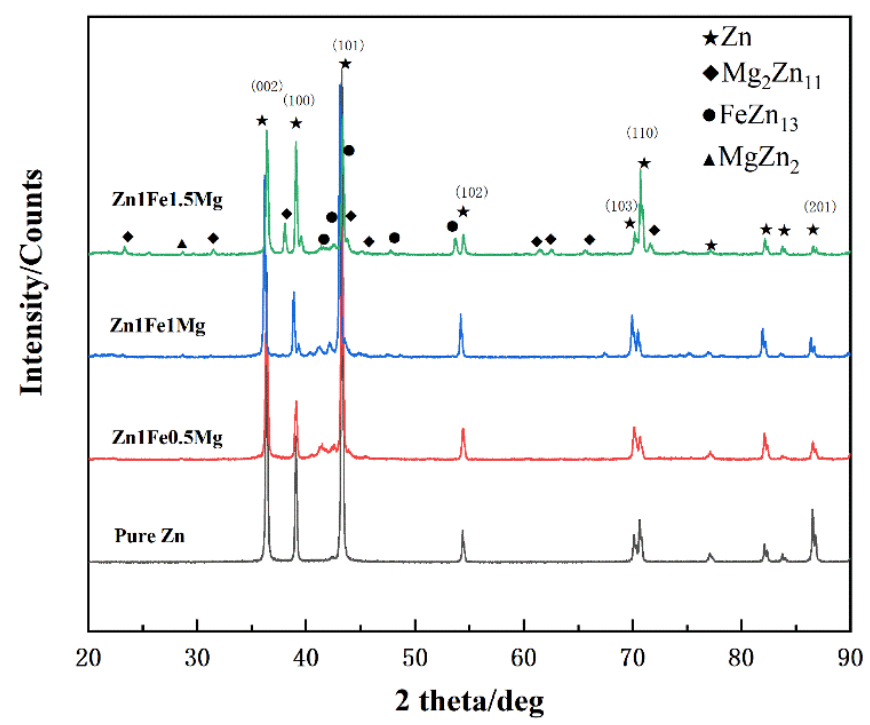

Figure 2. The comparison of XRD patterns of Zn1FexMg alloys. 


\subsection{Mechanical Properties}

\subsubsection{Hardness Test}

The hardness values of the alloys with different $\mathrm{Mg}$ contents are shown in Figure 3a. It was observed that hardness of Zn1FexMg alloys increased with an increase in $\mathrm{Mg}$ content, from approximately $38 \mathrm{HB}$ for pure $\mathrm{Zn}$ up to $145 \mathrm{HB}$ for the Zn1Fe1.5Mg alloy, and there was an increase of $280.5 \%$. This behavior can be attributed to the significantly increasing fraction of the hard $\mathrm{Mg}_{2} \mathrm{Zn}_{11}+\mathrm{Zn}$ eutectic microstructure with an increase in $\mathrm{Mg}$ content (see Figure 1). The alloys exhibited the characteristics, such as soft matrix and hard spots. Therefore, the proportion of the second phase affected the hardness value of the alloy. Thus, an increase in Mg content greatly improved the hardness value of the alloys.
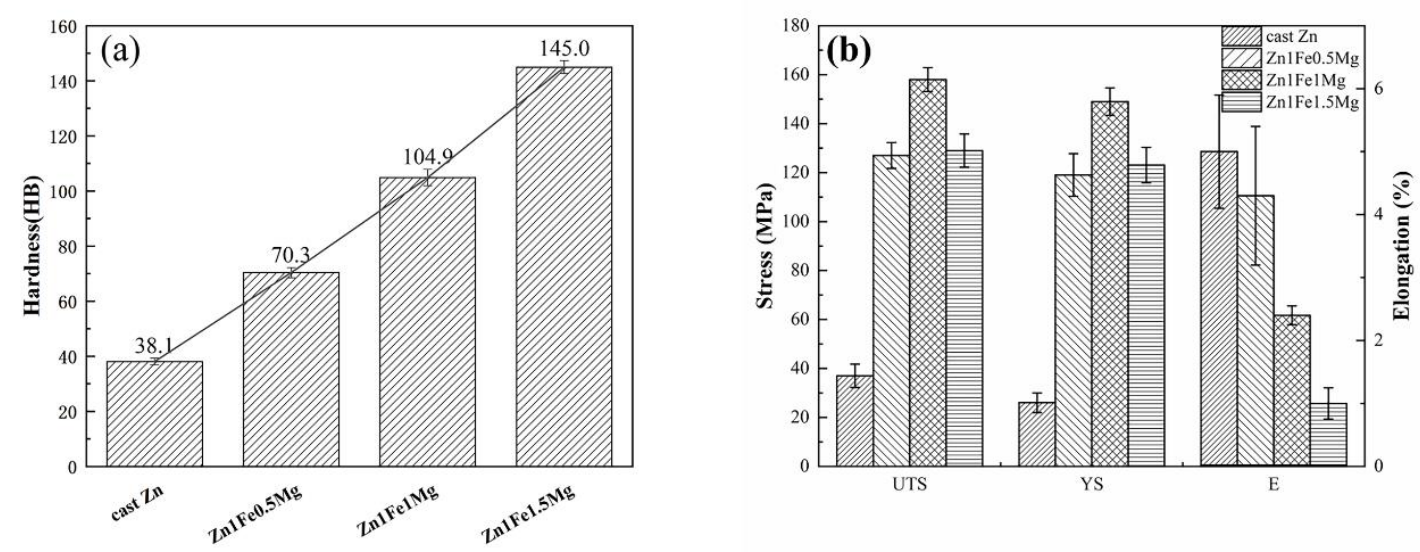

Figure 3. Microhardness (a) and tensile properties (b) of alloys with different $\mathrm{Mg}$ contents.

\subsubsection{Tensile Properties}

The effects of Mg elements on the mechanical properties of the Zn1FexMg alloys are shown in Figure $3 \mathrm{~b}$. Pure $\mathrm{Zn}$ had poor mechanical properties. Its ultimate tensile strength, yield strength, and elongation were $37 \mathrm{MPa}, 26 \mathrm{MPa}$, and 5\%, respectively. Compared with pure Zn, the UTS and yield strength (YS) of the alloys were significantly increased and there was a slight decrease in elongation. The tensile strength of the alloys increased initially and then decreased with an increase in Mg content, reaching a maximum of $157 \mathrm{MPa}$ in $\mathrm{Zn} 1 \mathrm{Fe} 1 \mathrm{Mg}$. This is because when the $\mathrm{Mg}$ content was $\leq 1 \mathrm{wt} \%$, the network hard eutectic structures greatly limited the grain size of $\mathrm{Zn}$ crystals and they also hindered the dislocation motion of grains, thus improving the mechanical properties of the alloy. The UTS of $\mathrm{Zn} 1 \mathrm{Fe} 1.5 \mathrm{Mg}$ was less than that of Zn1Fe1Mg. The high-volume fraction brittle-coarse eutectic mixtures and massive $\mathrm{FeZn}_{13}$ needle-like phases greatly reduced the resistance of the alloy to crack initiation and propagation when it was stretched. However, due to the high-volume fraction hard-brittle eutectic structure phases, the elongation of all alloys was less than that of pure $\mathrm{Zn}$. Casting defects also contributed to the deterioration in elongation.

Figure 4 illustrates fracture morphologies of the alloys after tensile testing. Figure $4 \mathrm{a}$ shows that pure $\mathrm{Zn}$ showed a brittle intercrystalline fracture without any plastic deformation. The main fracture type of the alloys shown in Figure $4 \mathrm{~b}-\mathrm{d}$ was transgranular cleavage fracture, which had relatively obvious river-shaped tear ridges. The tear ridges surrounded the cleavage plane and cleavage steps. There were also some intracrystalline cracks on the cleavage plane. Zn crystals were in a brittle fracture state, and the fracture was reflected as the cleavage plane. The eutectic structures surrounding the dissociation surface were in a plastic fracture state. $\mathrm{The}^{\mathrm{Fe}} \mathrm{Zn}_{13}$ phase exhibited a brittle fracture, which existed as a coarse cleavage plane in the fracture morphology, and it showed a deeper contrast than the $\mathrm{Zn}$ dendritic grains. The area of each cleavage plane was smaller than that of pure $\mathrm{Zn}$, and the fraction of the river-like pattern increased significantly, showing the characteristics of a transgranular fracture with an increase in $\mathrm{Mg}$ content. There was a tendency for transformation of a brittle fracture to plastic 
fracture with an increase in $\mathrm{Mg}$ content from $0.1 \mathrm{wt} \%$ to $1.0 \mathrm{wt} \%$, and the strength and plasticity of the alloy increased accordingly. The Zn1Fe1.5Mg alloy showed completely different fracture morphology than the other alloys. The fracture occurred at the intergranular plane, and it was almost a brittle fracture. There were large amounts of eutectic particles on a flat fracture surface around the coarse $\mathrm{Zn}$ crystals and FeZn $\mathrm{n}_{13}$ phases, which caused decreases in the plasticity and strength of the alloy.
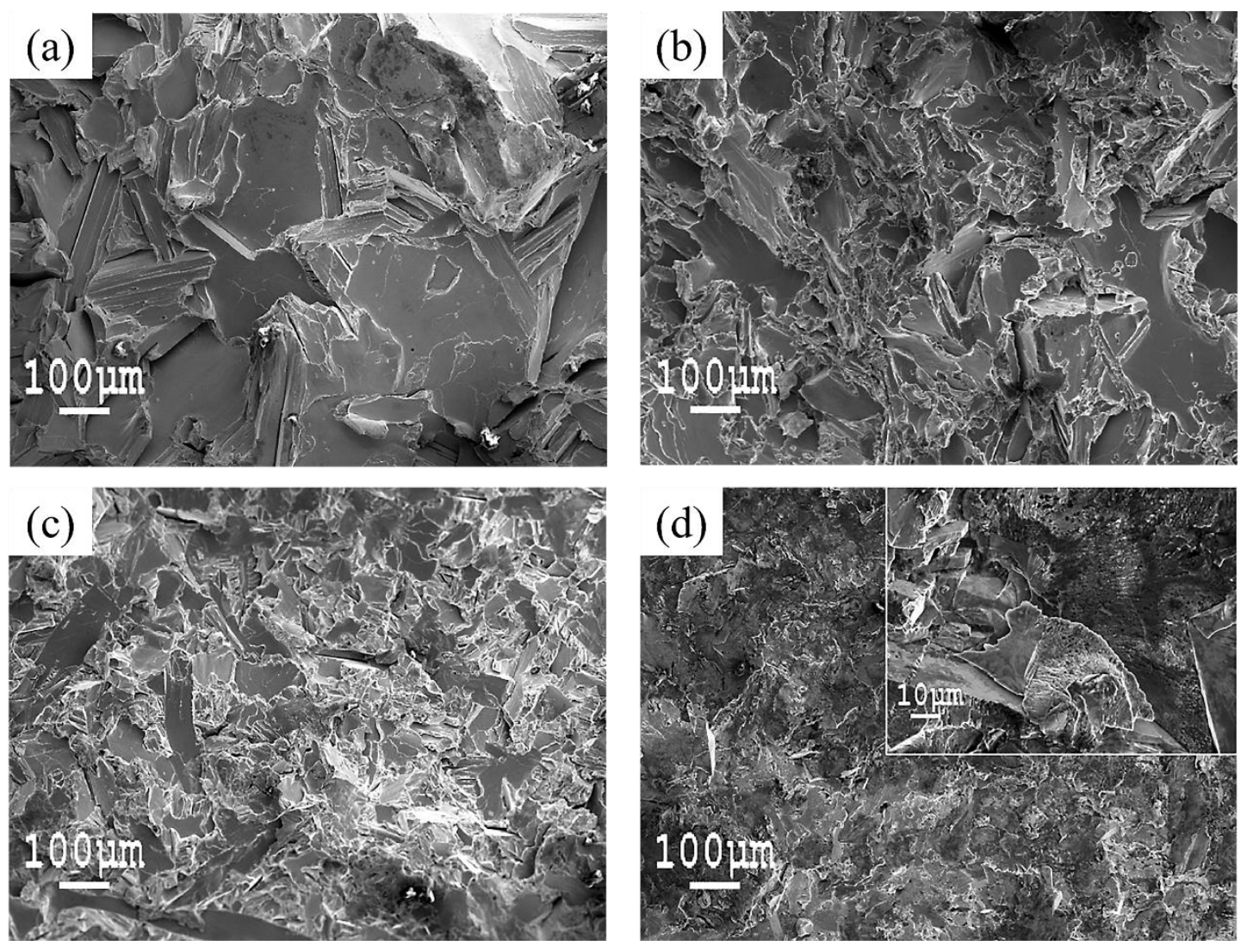

Figure 4. Fracture surfaces of the alloys after tensile tests: (a) Cast $\mathrm{Zn}$, (b) $\mathrm{Zn} 1 \mathrm{Fe} 0.5 \mathrm{Mg}$, (c) $\mathrm{Zn} 1 \mathrm{Fe} 1 \mathrm{Mg}$, (d) $\mathrm{Zn} 1 \mathrm{Fe}-1.5 \mathrm{Mg}$.

Due to less solubility of $\mathrm{Mg}$ in $\mathrm{Zn}$, which is only about $0.02-0.03 \mathrm{wt} \%$ [21], it is generally believed that the solid solution strengthening effect of $\mathrm{Mg}$ on the $\mathrm{Zn}-\mathrm{Mg}$ binary alloy is less pronounced. Thus, as-cast Zn1FexMg alloys were mainly affected by grain boundary strengthening and grain refinement. The intermetallic compounds formed by the addition of $\mathrm{Mg}$ and Fe elements prevented slippage of the alloy crystals and controlled the dislocation, which improved the strength of the alloy; this can also explain why the plasticity of the Zn1FexMg alloy was lower than that of pure Zn. However, when the $\mathrm{Mg}$ content was high ( $\mathrm{Zn} 1 \mathrm{Fe} 1.5 \mathrm{Mg}$ alloy), the high-volume fraction and coarse eutectic structures increased the brittleness of the alloy, which led to a decrease in the tensile strength. Zn1Fe1Mg exhibited superior mechanical properties compared to the other alloys.

\subsection{Corrosion Properties}

\subsubsection{Electrochemical Potentiodynamic Polarization Test}

The potentiodynamic curves for alloys are shown in Figure 5, and Table 3 shows the electrochemical results after potential kinetic polarization. The self-corrosion potential of the alloy in SBF at room temperature was slightly lower than that of pure $\mathrm{Zn}$. Except for the $\mathrm{Zn} 1 \mathrm{Fe} 1.5 \mathrm{Mg}$, it seems that there are two minimum current density positions in each curve. This feature represents the formation of the corrosion layer on the surface of the alloy. When the applied potential of the polarization 
experiment becomes higher than the self-corrosion potential of the alloy during the test, there is a potential difference between the sample and the applied potential. At this time, the sample acts as an anode and corrodes quickly, producing a dense corrosion product film layer, resulting in the phenomenon of increase in surface self-corrosion potential. Because the $\mathrm{Zn} 1 \mathrm{Fe} 1.5 \mathrm{Mg}$ alloy contains a higher content of $\mathrm{Mg}$, it produces more non-compact corrosion product films containing $\mathrm{Mg}$ in the test, so the second minimum current density point in the corresponding curve is not obvious. This occurred because $\mathrm{Mg}_{2} \mathrm{Zn}_{11}$ produced by the addition of $\mathrm{Mg}$ caused microcell corrosion with the other phases. The electrochemical corrosion rates of alloys were significantly lower than that of pure $\mathrm{Zn}$, which was different from the results of the immersion test. This may be because the alloy samples were more likely to produce insoluble oxide films than pure $\mathrm{Zn}$ and this led to passivation during the process of electrochemical polarization test, which caused the electrode potential to deviate from the self-corrosion potential, resulting in a decrease in the corrosion rate.

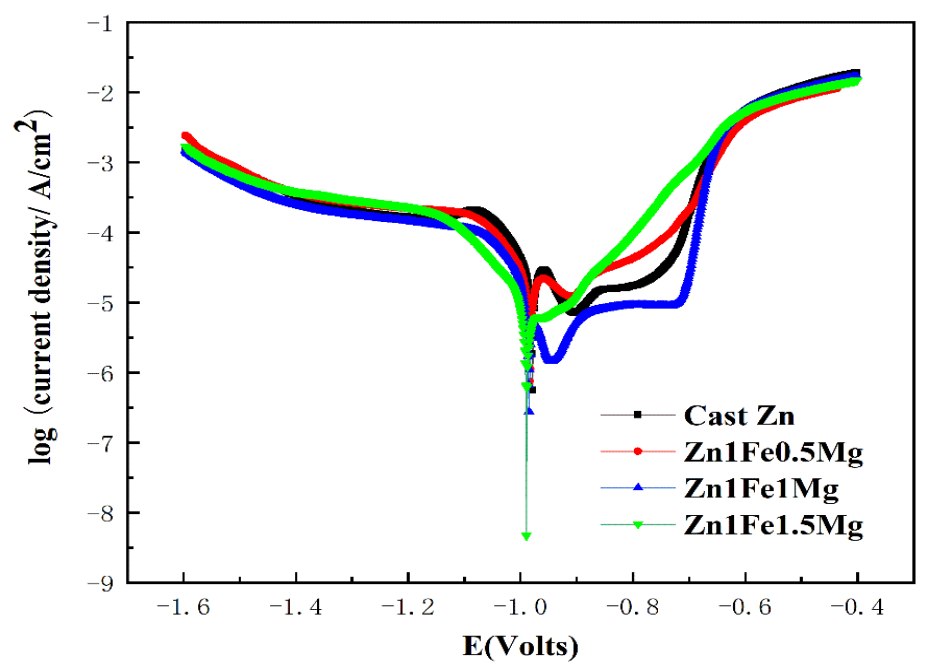

Figure 5. Potentiodynamic polarization analysis of tested $\mathrm{Zn}$ alloys in simulated body fluid (SBF) solution at ambient temperature.

Table 3. Fitted results of polarization curves in Figure 5: Ecorr is Corrosion Potential; icorr is corrosion current density; C.R is the corrosion rate.

\begin{tabular}{ccc}
\hline Alloys & $\mathbf{E}_{\text {corr }}(\mathbf{V}$ vs. SCE $)$ & $\mathbf{i}_{\text {corr }}\left(\mathbf{m A} / \mathbf{c m}^{2}\right)$ \\
\hline Cast Zn & -0.97 & $5.44 \times 10^{-5}$ \\
Zn 1Fe0.5Mg & -0.98 & $2.44 \times 10^{-5}$ \\
Zn1Fe1Mg & -0.98 & $4.18 \times 10^{-5}$ \\
Zn1Fe1.5Mg & -0.99 & $1.54 \times 10^{-5}$ \\
\hline
\end{tabular}

\subsubsection{EIS Spectra}

The corresponding simulation curves of EIS spectra of Zn1FexMg and the fitted equivalent circuit (EC) are shown in Figure 6. The Nyquist diagrams for alloys showed the capacitive loop at all frequencies, which represented the charge transfer process and double-layer capacitance. The impedance values of $\mathrm{Zn} 1 \mathrm{FexMg}$ were lower than those of pure $\mathrm{Zn}$. With an increase in $\mathrm{Mg}$ content, the impedance value of the alloy decreased gradually. This indicated that the addition of $\mathrm{Mg}$ may cause microcell corrosion with the other phases, which reduced the corrosion resistance of the alloy. In the Bode diagram (see Figure $6 \mathrm{~b}$ ), Zn1FexMg alloys had lower peak value phase angles than pure Zn, indicating that their corrosion resistance was poor compared to that of cast $Z n$. Figure $6 \mathrm{~d}$,e shows the simulation curve of the Zn1Fe1Mg alloy. The error in fitting data was less than 5\%. The EC, depicted in Figure $6 \mathrm{~g}$, describing a bilayer surface was used to fit the EIS spectra. Constant phase elements (CPE) were used 
instead of capacitors to compensate for surface inhomogeneity. This model demonstrated the general corrosion process.
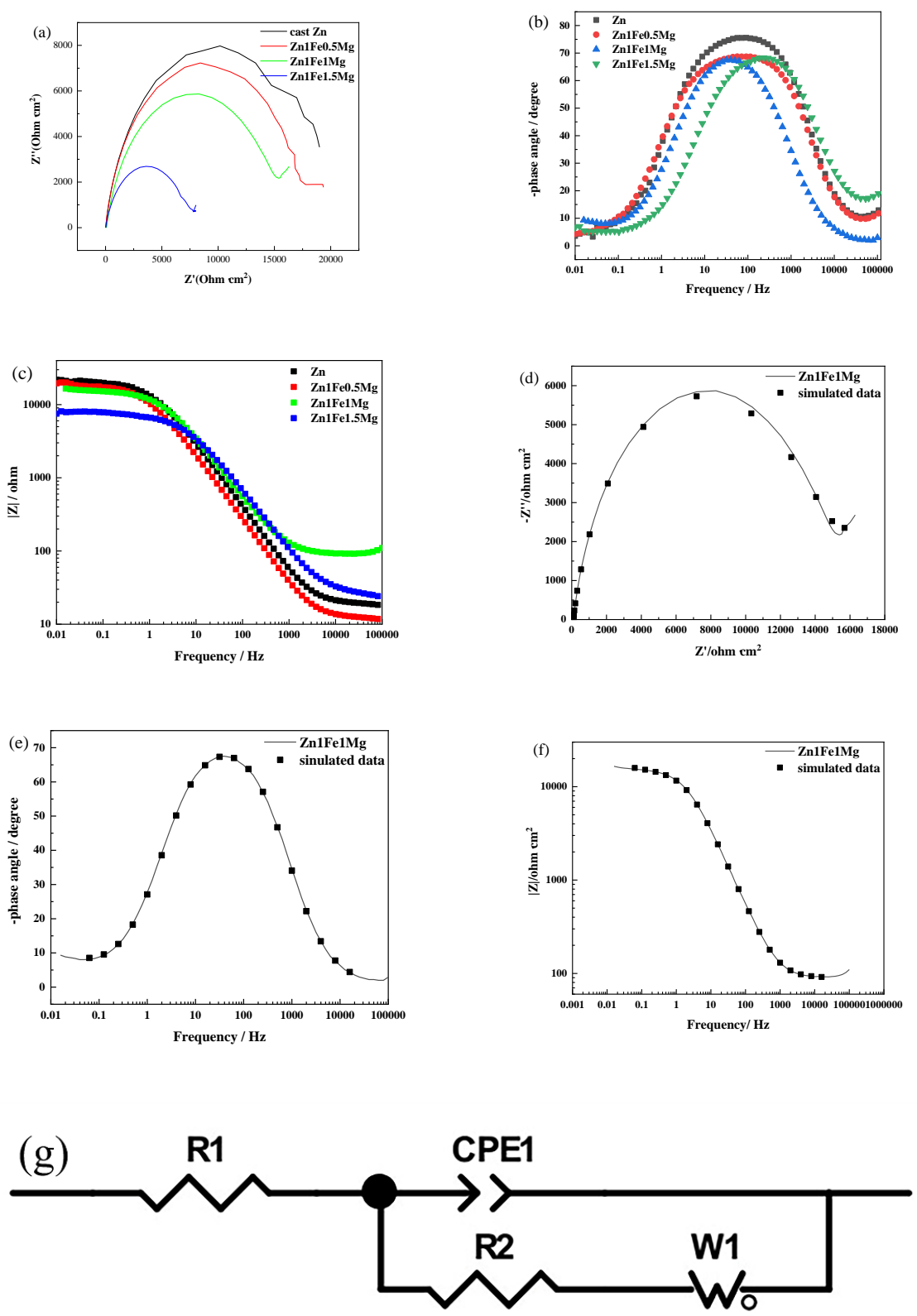

Figure 6. Electrochemical impedance spectroscopy (EIS) spectra of Zn-Fe-Mg in SBF solution at room temperature: (a) Nyquist diagram comparison and simulated results of the $\mathrm{Zn}-\mathrm{Fe}-\mathrm{Mg}$ alloy: (b) Bode phase angle diagram; (c) Bode impedance-frequency diagram; (d-f) Nyquist diagram, phase angle diagram, and impedance-frequency diagram of Zn1Fe1Mg and simulated data; (g) The equivalent circuit of EIS spectra for the Zn-1Fe-Mg alloy: R1 is the solution resistance; CPE1 is constant phase angle element; R2 is the charge-transfer resistance; W1 is the Warburg finite-length diffusion impedance.

\subsubsection{Immersion Test}

The alloy immersion experiment was performed in SBF solution to simulate corrosion of the alloy in the human body. There was an absence of gas evolution during the experiment, which is consistent with the previous research [31]. Figure 7a shows that without renewing the SBF solution, the $\mathrm{pH}$ value of the solution, in which the sample was soaked, gradually increased with the passage of time. This meant that corrosion of the alloy in the SBF solution caused consumption of hydrogen ions 
in the solution, thus making the solution alkaline. However, there is a free flow of body fluids in the human body and there is a minimal change in the $\mathrm{pH}$ value. Therefore, the SBF solution was frequently renewed during the immersion experiment. Figure $7 \mathrm{~b}$ shows the average corrosion rates of alloys after 30 days of immersion in SBF solution at $37^{\circ} \mathrm{C}$. Corrosion rates of all alloys were higher than that of pure $\mathrm{Zn}$, and the corrosion rate rapidly increased with an increase in $\mathrm{Mg}$ content. The corrosion rate of the $\mathrm{Zn} 1 \mathrm{Fe} 1.5 \mathrm{Mg}$ alloy was almost 2.5 times that of pure $\mathrm{Zn}$. Rapid corrosion of alloys may have occurred due to microcell corrosion caused by the high potential difference between $\mathrm{Mg}_{2} \mathrm{Zn}_{11}$ and $\mathrm{FeZn}_{13}$. Thus, the increase in the volume fraction of the eutectic structure significantly improved the corrosion rate of the alloy.
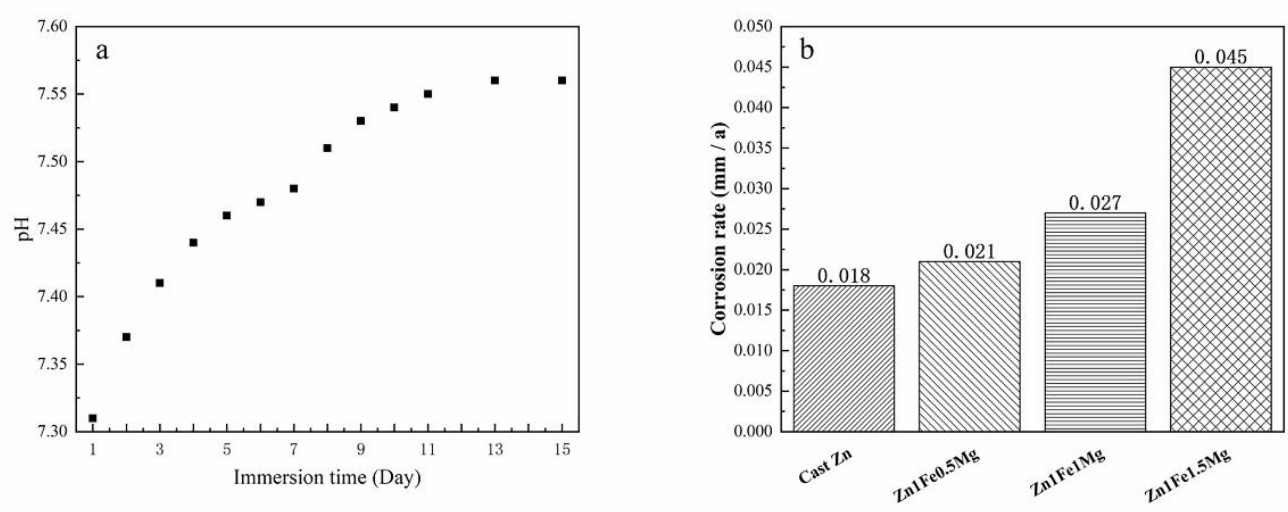

Figure 7. Change in the $\mathrm{pH}$ value of SBF solution with time after soaking the alloy (the ratio was $25 \mathrm{~mL} / 1 \mathrm{~cm}^{2}$ ) (a) and Corrosion rates of alloys in SBF solution(b).

Figure 8a-d show surface morphologies of alloys immersed in SBF solution for 30 days and then after removal of the corrosion products. It showed that the corrosion types in studied alloys were pitting corrosion and intergranular corrosion. Before the immersion test, the surfaces of tested alloys were already covered with insoluble protective films. $\mathrm{Cl}^{-}$in the SBF reacted with the passivation film to disrupt the integrity of the passivation film and expose the alloy surface. The exposed surface (anode) and the passivation area (cathode) formed the active-passive corrosion cell, which caused pitting corrosion. In areas of corrosion pits, eutectic structures showed complete dissolution, causing gaps between $\mathrm{Zn}$ grains. $\mathrm{Zn}$ grains were severely corroded with obvious corrosion marks. The FeZn 13 phase had a low corrosion degree and maintained high integrity, which prevented premature failure of the test sample. At the same time, the $\mathrm{Mg}_{2} \mathrm{Zn}_{11}$ phase located at the grain boundary had a lower self-corrosion potential than the other phases; therefore, the grain boundary showed high activity, which caused intergranular corrosion due to the mechanism of microcell corrosion. With an increase in $\mathrm{Mg}$ content, the depth of pitting pits increased and intergranular corrosion became more severe. Figure $8 \mathrm{e}, \mathrm{f}$ show the surface morphology of the $\mathrm{Zn} 1 \mathrm{Fe} 1 \mathrm{Mg}$ alloy before removal of the corrosion products after SBF immersion for 30 days and 60 days. The corrosion product layer on alloys immersed for 30 days was very loose and porous, and the surface of the alloy was exposed through the micropores. Compared with the corrosion product layer on alloys immersed for 30 days, the corrosion product layer on alloys immersed for 60 days was denser, had a barely visible alloy surface, and showed growth of many white precipitates. The EDS results of corrosion products are shown in Figure $8 \mathrm{~g}, \mathrm{~h}$. The chemical elements of corrosion products were mainly $\mathrm{Zn}, \mathrm{Ca}, \mathrm{P}, \mathrm{O}, \mathrm{C}, \mathrm{Cl}, \mathrm{S}$, and a small amount of $\mathrm{Mg}$ and $\mathrm{K}$. The results of EDS combined with the Pourbaix diagrams of the $\mathrm{Zn}-\mathrm{x}-\mathrm{H} 2 \mathrm{O}(\mathrm{x}=\mathrm{p}, \mathrm{s}, \mathrm{c}, \mathrm{cl}$, etc) system [11] indicated that the corrosion products comprised zinc phosphates, zinc carbonates, zinc hydroxide, and calcium phosphate. 

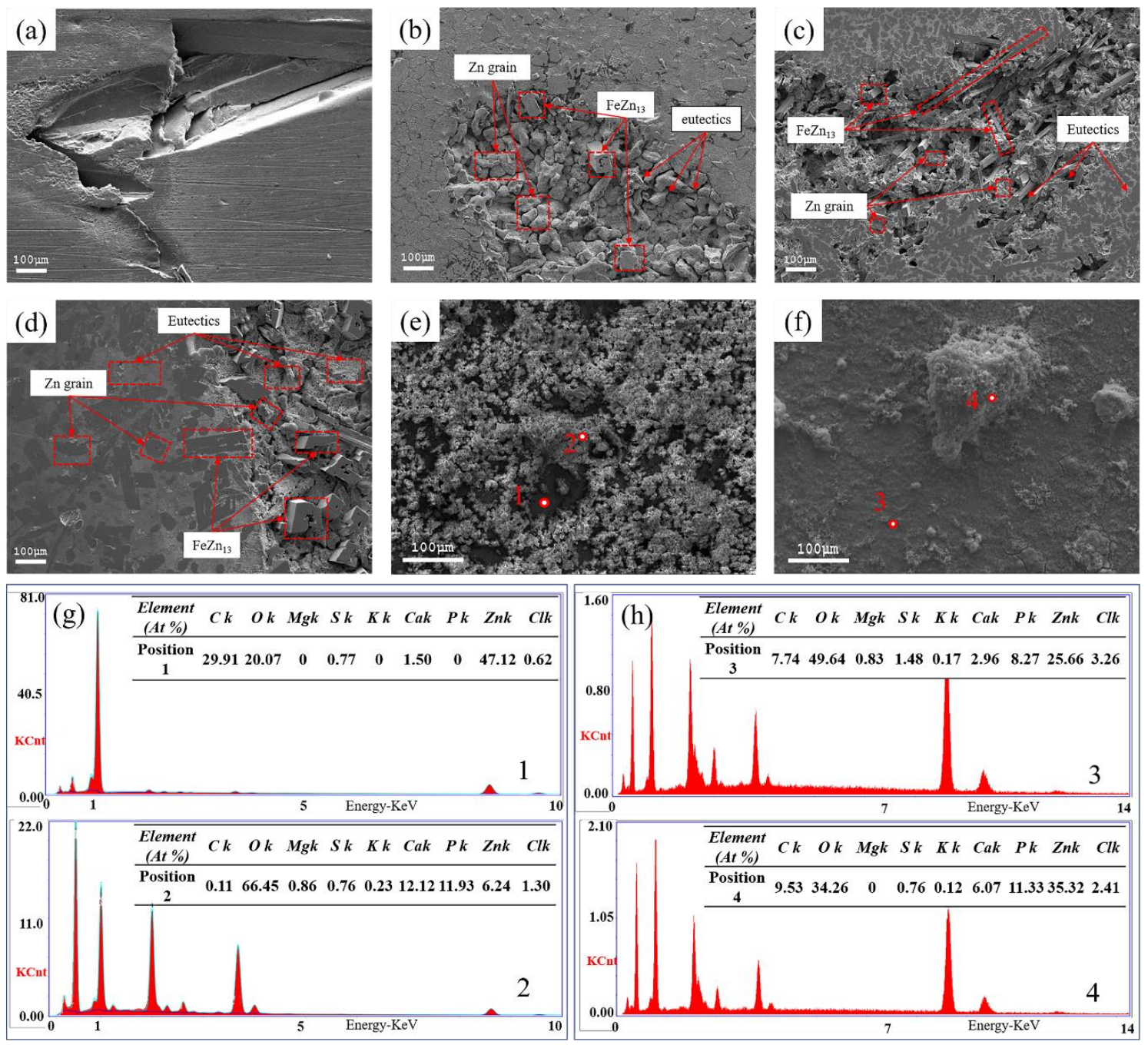

Figure 8. SEM micrographs of surface morphologies of (a) pure Zn, (b) Zn1Fe0.5Mg, (c) Zn1Fe1Mg, and (d) $\mathrm{Zn} 1 \mathrm{Fe} 1.5 \mathrm{Mg}$ alloys with the removal of surface corrosion products after immersion in SBF solution for 30 days; (e,f) surface morphologies of Zn1FeMg immersed in SBF for 30 days and 60 days, respectively; (g,h) EDS result corresponding to the area in $(\mathbf{e}, \mathbf{f})$, respectively.

\subsubsection{Corrosion Model of Zn1FexMg}

The effect of Mg elements on the corrosion mechanism of the alloy can be explained by the interaction between the eutectic structure, $\mathrm{FeZn}_{13}$ phase, and the $\mathrm{Zn}$ crystals. Based on the above results and related literature, an in vitro corrosion model of the $\mathrm{Zn} 1 \mathrm{MgxFe}$ alloy-liquid interface was proposed, as shown in Figure 9. The corrosion behavior of the alloy in SBF solution can be inferred as follows:

(1) The alloy sample had oxide film protective layers before immersion, which mainly included $\mathrm{ZnO}$, $\mathrm{MgO}$, and a small amount of iron oxide (see Figure 9a). $\mathrm{MgO}$ film layers were loose and porous. Thus, electrolytes in SBF solution were exposed to the surface of the studied alloys through micropores in the $\mathrm{MgO}$ film layers, causing pitting corrosion of the alloy surface. $\mathrm{The}^{\mathrm{Mg}} \mathrm{Zn}_{11}$ had a lower self-corrosion potential than the other structures. Thus, grain boundaries could be corroded preferentially, and an increase in Mg element aggravated this phenomenon. Dissolution of the eutectic structure allowed the fresh SBF solution to make contact with the Zn grains, causing corrosion of the matrix (see Figure $9 \mathrm{~b}$ ). Corrosion of the zinc matrix was accompanied by 
reduction in the zinc solution in the anode and oxygen in the cathode, and the reactions were as follows:

anodic reaction:

$$
\mathrm{Zn}(\mathrm{Mg}) \rightarrow \mathrm{Zn}^{2+}+2 e
$$

cathodic reaction:

$$
2 \mathrm{H}_{2} \mathrm{O}+\mathrm{O}_{2}+4 e \rightarrow 4 \mathrm{OH}^{-}
$$

overall reaction:

$$
2 \mathrm{Zn}(\mathrm{Mg})+2 \mathrm{H}_{2} \mathrm{O}+\mathrm{O}_{2} \rightarrow 4 \mathrm{Zn}(\mathrm{Mg})(\mathrm{OH})_{2}
$$

(2) The eutectic structures were corroded very quickly, which made deposition and concentration of $\mathrm{Mg}(\mathrm{OH})_{2}$ on the alloy surface difficult. Thus, $\mathrm{Mg}(\mathrm{OH})_{2}$ could not provide an effective barrier to further corrosion protection. The zinc hydroxide film covered the surface of the alloy, which could effectively prevent the dissolution of Zn. The results of EDS (see Figure 8g,h) showed that almost all corrosion products were enriched in $\mathrm{Cl}$ element. However, $\mathrm{Cl}^{-}$in the SBF solution disrupted the balance between the formation and dissolution of zinc hydroxide and reacted with it to form chlorohydroxy compounds. Since the self-corrosion potential of the $\mathrm{FeZn}_{13}$ phase was higher than that of the other phases, the areas adjacent to the $\mathrm{FeZn}_{13}$ phase corroded faster than those at other positions due to high potential difference (see Figure 9c). The reaction for formation of chlorohydroxy compounds was as follows:

$$
6 \mathrm{Zn}(\mathrm{OH})_{2}+\mathrm{ZnCl}_{2} \leftrightarrow 7 \mathrm{ZnCl} 2(\mathrm{OH})_{12}(s)
$$

(3) As the corrosion process continued, corrosion areas gradually extended from the position of the eutectic structure to the Zn matrix. Deep corrosion pits were formed (see Figure 9d). The EDS result shows a high content of $\mathrm{Zn}, \mathrm{C}$, O element and a few $\mathrm{Ca}$ in position 1 (see Figure 8e), indicating the formation of zinc carbonate, which can effectively improve the corrosion resistance of $\mathrm{Zn}$ by promoting the formation of zinc hydroxide [12]:

$$
\begin{aligned}
& 5 \mathrm{Zn}^{2+}+2 \mathrm{HCO}_{3}^{-}+6 \mathrm{H}_{2} \mathrm{O} \rightarrow \mathrm{Zn}_{5}(\mathrm{OH})_{6}\left(\mathrm{CO}_{3}\right)_{2}(\mathrm{~s})+8 \mathrm{H}^{+} \\
& 2 \mathrm{H}^{+}+2 \mathrm{HCO}_{3}^{-}+\mathrm{H}_{2} \mathrm{O}+5 \mathrm{ZnO}(\mathrm{s}) \rightarrow \mathrm{Zn}_{5}(\mathrm{OH})_{6}\left(\mathrm{CO}_{3}\right)_{2}(s)
\end{aligned}
$$

(4) With continuous horizontal and vertical expansion of the pitting corrosion area, the corrosion product layer became denser. The presence of carbonate in corrosion products promoted the deposition of phosphate. The discovery of $\mathrm{Ca}, \mathrm{Zn}$ and $\mathrm{P}, \mathrm{O}$ elements in the EDS results proved the existence of phosphate. The presence of zinc phosphate could promote the proliferation of bone cells. According to the following reaction, solid surface films could be formed in an aqueous solution containing phosphate, which could significantly inhibit the dissolution of $\mathrm{Zn}$ [31]:

$$
6 \mathrm{Ca}^{2+}\left(\mathrm{Zn}^{2+}\right)+2 \mathrm{HPO}_{4}^{2-}+2 \mathrm{H}_{2} \mathrm{PO}_{4}^{-}+6 \mathrm{OH}^{-} \rightarrow 2(\mathrm{Ca}, \mathrm{Zn})_{3}\left(\mathrm{PO}_{4}\right)_{2}+6 \mathrm{H}_{2} \mathrm{O}
$$

(5) As the alloy continued to corrode, the corrosion products gradually increased. Even small parts of $\mathrm{Zn}$ grains peeled off due to complete dissolution of the eutectic structures around the $\mathrm{Zn}$ grains. Relatively complete FeZn $\mathrm{n}_{13}$ phases were present and they still provided support (see Figure 9e).

The corrosion rates of alloys could simply indicate the amount of Zn element released, which helps to infer the potential toxicity of the implant in the human body from a biocompatibility viewpoint. We assume that a HA5.0 bone screw was made using Zn1FexMg with a working part size of $\varphi 5 \times 50 \mathrm{~mm}$. The corrosion rate of the screw in a neutral environment was about $0.021-0.045 \mathrm{~mm} / \mathrm{a}$, as indicated in Figure $7 \mathrm{~b}$. Thus, the average daily $\mathrm{Zn}$ absorption from this screw can be calculated to be about $0.66-1.4 \mathrm{mg} / \mathrm{d}$, which was far below the toxicity limit for $\mathrm{Zn}(100-150 \mathrm{mg} / \mathrm{d})$. 

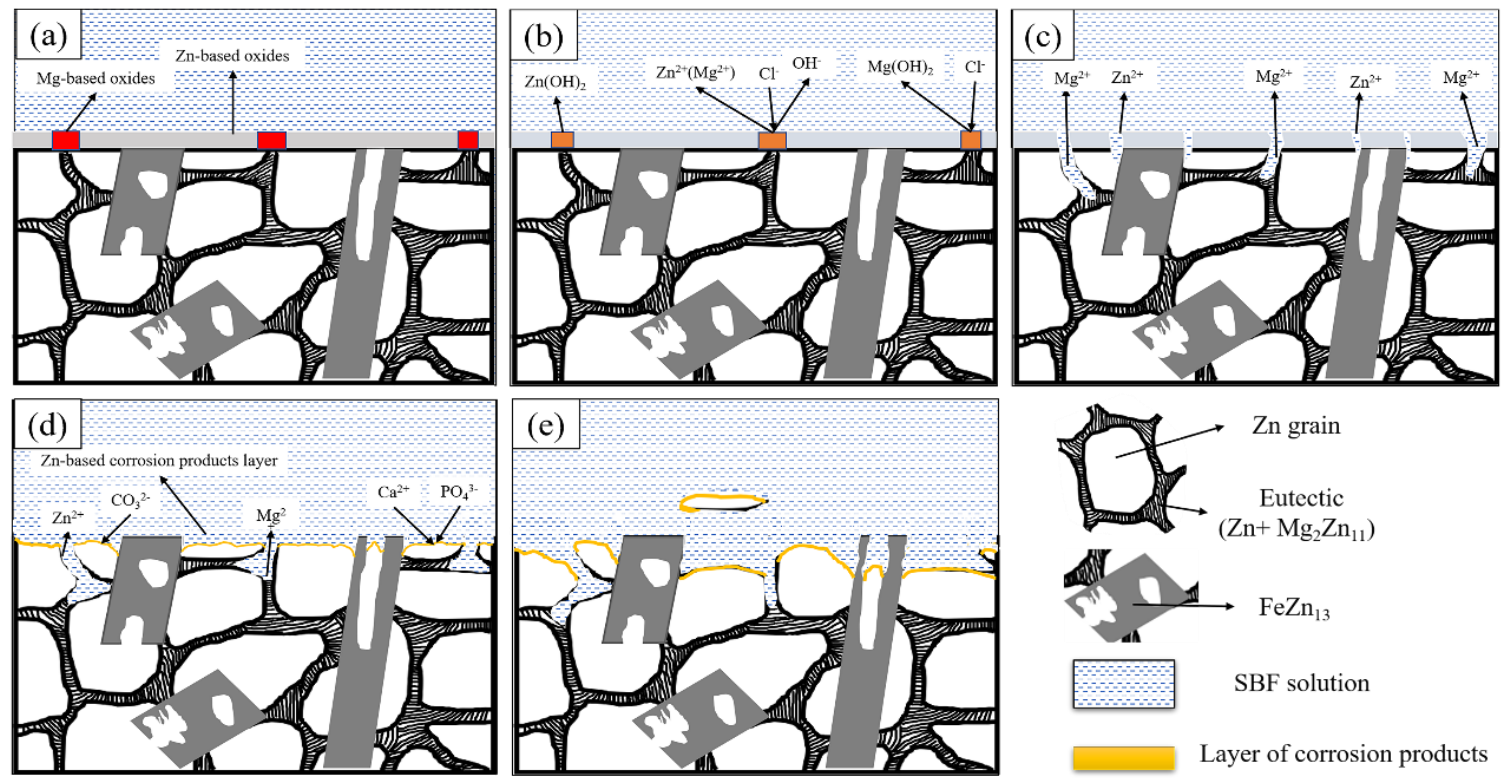

SBF solution

Layer of corrosion products

Figure 9. Schematic diagram of in vitro biocorrosion of the $\mathrm{Zn1FexMg}$ alloy in simulated body fluids: (a-e) are the sequence from the beginning of corrosion to the detachment of a small part of the Zn Matrix.

\section{Conclusions}

$\mathrm{Zn}-1 \mathrm{Fe}-\mathrm{xMg}$ alloys comprised primary dendritic $\mathrm{Zn}$ grains, $\mathrm{FeZn}_{13}$ prismatic structures, and the eutectics of $\mathrm{Zn}+\mathrm{Mg}_{2} \mathrm{Zn}_{11}$. With an increase in $\mathrm{Mg}$ content, the fraction of eutectic structures increased gradually; this made the $\mathrm{Zn}$ crystals more uniform and finer, but it also caused slight coarsening of $\mathrm{FeZn}_{13}$. Hardness, yield strength, and ultimate tensile strength of the alloys increased significantly with an increase in $\mathrm{Mg}$ content. The corrosion behavior evaluation by the potentiodynamic polarization test, EIS impedance test, and immersion test showed that the increase in $\mathrm{Mg}$ content exacerbated microcell corrosion between different phases, which reduced the impedance and self-corrosion potential of the alloys, thus improving the corrosion rate of alloys in SBF solution. Zn1Fe1Mg possessed superior comprehensive mechanical properties (its hardness, tensile strength, yield strength, and elongation values were $105 \mathrm{HB}, 157 \mathrm{MPa}, 146 \mathrm{MPa}$, and $2.3 \%$, respectively) and had an appropriate corrosion rate $(0.027 \mathrm{~mm} / \mathrm{a})$, thus revealing that it is a preferred candidate for biodegradable implant material.

Author Contributions: Conceptualization, K.Z. and Y.L.; methodology, G.S.; software, X.L.; validation, G.S., Y.L. and K.W.; formal analysis, J.Y.; investigation, J.Y.; resources, M.M.; data curation, M.M.; writing—original draft preparation, P.X.; writing-review and editing, P.X.; visualization, M.M.; supervision, K.Z.; project administration, X.L.; funding acquisition, Y.L. All authors have read and agreed to the published version of the manuscript.

Funding: This research received no external funding.

Acknowledgments: The authors would like to thank the staff at Grimat Engineering institute Co., Ltd. for their time and instrument use. We thank our group teachers and classmates for their help and support. We would also like to appreciate the teachers and classmates of Beijing University of Science and Technology and for their help and support.

Conflicts of Interest: The authors declare no conflict of interest.

\section{References}

1. Mostaed, E.; Sikora-Jasinska, M.; Drelich, J.W.; Vedani, M. Zinc-based alloys for degradable vascular stent applications. Acta Biomater. 2018, 71, 1-23. [CrossRef]

2. Zheng, Y.F.; Gu, X.N.; Witte, F. Biodegradable metals. Mater. Sci. Eng. R Rep. 2014, 77, 1-34. [CrossRef]

3. Sikora-Jasinska, M.; Paternoster, C.; Mostaed, E.; Tolouei, R.; Casati, R.; Vedani, M.; Mantovani, D. Synthesis, mechanical properties and corrosion behavior of powder metallurgy processed Fe/Mg2Si composites for biodegradable implant applications. Mater. Sci. Eng. C 2017, 81, 511-521. [CrossRef] [PubMed] 
4. Peuster, M.; Hesse, C.; Schloo, T.; Fink, C.; Beerbaum, P.; von Schnakenburg, C. Long-term biocompatibility of a corrodible peripheral iron stent in the porcine descending aorta. Biomaterials 2006, 27, 4955-4962. [CrossRef] [PubMed]

5. Peuster, M.; Wohlsein, P.; Brügmann, M.; Ehlerding, M.; Seidler, K.; Fink, C.; Brauer, H.; Fischer, A.; Hausdorf, G. A novel approach to temporary stenting: Degradable cardiovascular stents produced from corrodible metal-Results 6-18 months after implantation into New Zealand white rabbits. Heart 2001, 86, 563. [CrossRef] [PubMed]

6. Heublein, B.; Rohde, R.; Kaese, V.; Niemeyer, M.; Hartung, W.; Haverich, A. Biocorrosion of magnesium alloys: A new principle in cardiovascular implant technology? Heart 2003, 89, 651-656. [CrossRef] [PubMed]

7. Moravej, M.; Purnama, A.; Fiset, M.; Couet, J.; Mantovani, D. Electroformed pure iron as a new biomaterial for degradable stents: In vitro degradation and preliminary cell viability studies 虰. Acta Biomater. 2010, 6, 1843-1851. [CrossRef] [PubMed]

8. Pierson, D.; Edick, J.; Tauscher, A.; Pokorney, E.; Bowen, P.; Gelbaugh, J.; Stinson, J.; Getty, H.; Lee, C.H.; Drelich, J.; et al. A simplified in vivo approach for evaluating the bioabsorbable behavior of candidate stent materials. J. Biomed. Mater. Res. Part B Appl. Biomater. 2012, 100B, 58-67. [CrossRef]

9. Kubásek, J.; Vojtěch, D. Structural characteristics and corrosion behavior of biodegradable Mg-Zn, Mg-Zn-Gd alloys. J. Mater. Sci. Mater. Med. 2013, 24, 1615-1626. [CrossRef]

10. Li, L.; Gao, J.; Wang, Y. Evaluation of cyto-toxicity and corrosion behavior of alkali-heat-treated magnesium in simulated body fluid. Surf. Coat. Technol. 2004, 185, 92-98. [CrossRef]

11. Hiromoto, S.; Yamamoto, A. Control of degradation rate of bioabsorbable magnesium by anodization and steam treatment. Mater. Sci. Eng. C 2010, 30, 1085-1093. [CrossRef]

12. Tapiero, H.; Tew, K.D. Trace elements in human physiology and pathology: Zinc and metallothioneins. Biomed. Pharmacother. 2003, 57, 399-411. [CrossRef]

13. Bowen, P.; Shearier, E.; Zhao, S.; Guillory, R.J., II; Zhao, F.; Goldman, J.; Drelich, J. Biodegradable Metals for Cardiovascular Stents: From Clinical Concerns to Recent Zn-Alloys. Adv. Healthc. Mater. 2016, 5, 1121-1140. [CrossRef]

14. Rink, L. Zinc and the immune system. Proc. Nutr. Soc. 2000, 59, 541-552. [CrossRef]

15. Trumbo, P.; Schlicker, S.; Yates, A.A.; Poos, M. Dietary Reference Intakes for Energy, Carbohydrate, Fiber, Fat, Fatty Acids, Cholesterol, Protein and Amino Acids. J. Am. Diet. Assoc. 2002, 102, 1621-1630. [CrossRef]

16. Vojtěch, D.; Kubásek, J.; Šerák, J.; Novák, P. Mechanical and corrosion properties of newly developed biodegradable Zn-based alloys for bone fixation. Acta Biomater. 2011, 7, 3515-3522. [CrossRef]

17. Mostaed, E.; Sikora-Jasinska, M.; Mostaed, A.; Loffredo, S.; Demir, A.G.; Previtali, B.; Mantovani, D.; Beanland, R.; Vedani, M. Novel Zn-based alloys for biodegradable stent applications: Design, development and in vitro degradation. J. Mech. Behav. Biomed. Mater. 2016, 60, 581-602. [CrossRef]

18. Kafri, A.; Ovadia, S.; Goldman, J.; Drelich, J.; Aghion, E. The Suitability of Zn-1.3\%Fe Alloy as a Biodegradable Implant Material. Metals 2018, 8, 153. [CrossRef]

19. Kafri, A.; Ovadia, S.; Yosafovich-Doitch, G.; Aghion, E. In vivo performances of pure Zn and Zn-Fe alloy as biodegradable implants. J. Mater. Sci. Mater. Med. 2018, 29. [CrossRef]

20. Yue, R.; Huang, H.; Ke, G.; Zhang, H.; Pei, J.; Xue, G.; Yuan, G. Microstructure, mechanical properties and in vitro degradation behavior of novel Zn-Cu-Fe alloys. Mater. Charact. 2017, 134, 114-122. [CrossRef]

21. Butts, W.F.G.D.A. 11-Equilibrium diagrams. In Smithells Metals Reference Book, 8th ed.; Gale, W.F., Totemeier, T.C., Eds.; Butterworth-Heinemann: Oxford, UK, 2004; pp. 11-1-11-534.

22. Liu, X.; Sun, J.; Zhou, F.; Yang, Y.; Chang, R.; Qiu, K.; Pu, Z.; Li, L.; Zheng, Y. Micro-alloying with Mn in $\mathrm{Zn}-\mathrm{Mg}$ alloy for future biodegradable metals application. Mater. Des. 2016, 94, 95-104.

23. Xiao, C.; Wang, L.; Ren, Y.; Sun, S.; Zhang, E.; Yan, C.; Liu, Q.; Sun, X.; Shou, F.; Duan, J.; et al. Indirectly extruded biodegradable $\mathrm{Zn}-0.05 \mathrm{wt} \% \mathrm{Mg}$ alloy with improved strength and ductility: In vitro and in vivo studies. J. Mater. Sci. Technol. 2018, 34, 1618-1627.

24. Tang, Z.; Huang, H.; Niu, J.; Zhang, L.; Zhang, H.; Pei, J.; Tan, J.; Yuan, G. Design and characterizations of novel biodegradable Zn-Cu-Mg alloys for potential biodegradable implants. Mater. Des. 2017, 117, 84-94.

25. Yao, C.; Wang, Z.; Tay, S.L.; Zhu, T.; Gao, W. Effects of Mg on microstructure and corrosion properties of Zn-Mg alloy. J. Alloys Compd. 2014, 602, 101-107.

26. Liu, X.; Sun, J.; Qiu, K.; Yang, Y.; Pu, Z.; Li, L.; Zheng, Y. Effects of alloying elements (Ca and Sr) on microstructure, mechanical property and in vitro corrosion behavior of biodegradable $\mathrm{Zn}-1.5 \mathrm{Mg}$ alloy. J. Alloys Compd. 2016, 664, 444-452. 
27. Bakhsheshi-Rad, H.R.; Hamzah, E.; Low, H.T.; Cho, M.H.; Kasiri-Asgarani, M.; Farahany, S.; Mostafa, A.; Medraj, M. Thermal Characteristics, Mechanical Properties, In Vitro Degradation and Cytotoxicity of Novel Biodegradable Zn-Al-Mg and Zn-Al-Mg-xBi Alloys. Acta Metall. Sin. 2017, 30, 201-211.

28. Katarivas Levy, G.; Leon, A.; Kafri, A.; Ventura, Y.; Drelich, J.W.; Goldman, J.; Vago, R.; Aghion, E. Evaluation of biodegradable $\mathrm{Zn}-1 \% \mathrm{Mg}$ and $\mathrm{Zn}-1 \% \mathrm{Mg}-0.5 \% \mathrm{Ca}$ alloys for biomedical applications. J. Mater. Sci. Mater. Med. 2017, 28. [CrossRef]

29. ASTM G102-89 (2015) e1, Standard Practice for Calculation of Corrosion Rates and Related Information from Electrochemical Measurements; ASTM International: West Conshohocken, PA, USA, 2015. Available online: Www.astm.org (accessed on 10 October 2020).

30. ASTM NACE/ASTMG31-12a, Standard Guide for Laboratory Immersion Corrosion Testing of Metals; ASTM International: West Conshohocken, PA, USA, 2012. Available online: www.astm.org (accessed on 10 October 2020).

31. Zhang, X.G. Corrosion potential and corrosion current. In Corrosion and Electrochemistry of Zinc; Zhang, X.G., Ed.; Springer US: Boston, MA, USA, 1996; pp. 125-156.

Publisher's Note: MDPI stays neutral with regard to jurisdictional claims in published maps and institutional affiliations.

(C) 2020 by the authors. Licensee MDPI, Basel, Switzerland. This article is an open access article distributed under the terms and conditions of the Creative Commons Attribution (CC BY) license (http://creativecommons.org/licenses/by/4.0/). 